\title{
Safety assessment of omeprazole use: a review
}

\author{
Marcela Forgerini', Stephania Mieli", Patrícia de Carvalho Mastroianni"I \\ Universidade Estadual Paulista (UNESP), Araraquara (SP), Brazil
}

'BSc. Pharmacist and Master's Student in the Postgraduate Program on Pharmaceutical Sciences, Universidade Estadual Paulista (UNESP), Araraquara (SP), Brazil.

(Dorcid.org/0000-0002-2905-8519

"Undergraduate Pharmacy Student, Universidade Estadual Paulista (UNESP), Araraquara (SP), Brazil.

iDorcid.org/0000-0001-5002-966X

IIPhD. Pharmacist and Adjunct Professor, Department of Drugs and Medicines, Universidade Estadual Paulista (UNESP), Araraquara (SP), Brazil.

iDorcid.org/0000-0001-8467-7278

\section{KEY WORDS:}

Review.

Drug-related side effects and adverse reactions. Proton pump inhibitors.

Drug interactions.

Treatment outcome.

\begin{abstract}
BACKGROUND: Risks regarding hospital admission due to adverse drug reactions and drug interactions from use of omeprazole have been reported. The question guiding the present review was "Which adverse events occur in patients using omeprazole in a Food and Drug Administration-approved and/or off-label manner?" It was also proposed to evaluate the safety of use of omeprazole.

DESIGN AND SETTING: Qualitative narrative review with critical evaluation, in a public university. METHODS: The PubMed, SCOPUS, LILACS, SciELO, EMBASE and EBSCO databases were searched on July 31, 2018. Studies evaluating adverse events were screened.

RESULTS: 72 articles were included, among which 58 reported on adverse drug events (47, adverse drug reactions; 5, drug interactions; and 6, situations of ineffectiveness). 28 adverse drug reactions not described in compendia and drug leaflets were described in these studies: myocardial infarction (6); stroke (2); spontaneous abortion (1); proliferative changes (1); chills (1); heart failure (1); thrombosis (2); and dementia (1), among others. Severe adverse reactions, for instance cardiac problems, Steven-Johnson syndrome and proliferative changes, were identified. The antiplatelet effects of drugs such as clopidogrel, in patients who underwent heart-related surgery, increased the risk of developing cardiac problems, such as cardiovascular death, myocardial infarction and stroke. In newly transplanted patients, decreased absorption of mycophenolate mofetil occurred, thus leading to rejection of transplanted organs.

CONCLUSION: Use of omeprazole should be monitored primarily in patients with heart disorders using antiplatelet agents concomitantly, and in newly transplanted patients using mycophenolic acid, in order to avoid serious adverse reactions.
\end{abstract}

\section{INTRODUCTION}

Proton-pump inhibitors (PPIs) such as omeprazole are one of the most widely prescribed classes of drugs worldwide. PPIs are indicated for treatment of ulcers with or without Helicobacter pylori infection; for treatment of gastroesophageal reflux, Zollinger-Ellison disease, dyspepsia, esophagitis and gastritis; and for prevention of peptic ulcers in patients receiving nonsteroidal inflammatory agents (NSAIDs) and in patients with upper gastrointestinal bleeding. ${ }^{1}$ Therefore, they are medications that are ever-present in gastroenterologists' practice. ${ }^{2}$

Omeprazole is effective and safe most of the time. ${ }^{1}$ However, Mastroianni et al. ${ }^{3}$ found that omeprazole was the drug most commonly associated with hospital admission, in a survey on the prevalence of hospitalizations due to adverse drug reactions. In addition, the safety of a drug may change over time through increased use and according to patients' characteristics. Therefore, risk assessment is required. ${ }^{4}$

This context can be elucidated from reports on abusive use of omeprazole and irrational prescription of this drug. ${ }^{4}$ Thus, there have been studies reporting on the risks (adverse events) of use of omeprazole, such as: (a) gastric proliferative changes; ${ }^{5}$ (b) increased creatinine and urea levels, leading to acute interstitial nephritis ${ }^{6-8}$ and increased risk of developing chronic kidney disease; ${ }^{9}$ (c) increased risk of asthma concomitant with gastroesophageal reflux; ${ }^{10}$ (d) increased risk of infection by Clostridium difficile $;^{11-13}$ (e) decreased absorption of vitamin $\mathrm{B} ;{ }^{14}$ (f) steatorrhea caused by cystic fibrosis; $;^{15}$ (g) fracture with decreased calcium absorption; ${ }^{16,17}$ (h) gynecomastia; ${ }^{18}$ (i) hypomagnesemia; ${ }^{19}(\mathrm{j})$ hyponatremia; ${ }^{20}(\mathrm{k})$ spontaneous bacterial peritonitis; ${ }^{21} \mathrm{l}$ ) pneumonia; ${ }^{22}$ (m) anaphylactic reactions to omeprazole, ${ }^{23}$ and (n) risk of celiac disease. ${ }^{24}$

In addition, studies that evaluated the prevalence of hospital admission due to adverse drug events have cited omeprazole among the drugs that were possibly related to hospitalization, thus also suggesting that off-label use of omeprazole occurs frequently. ${ }^{23,24}$ Off-label use of drugs consists of their use for unapproved indications and usually occurs among polymedicated patients 
and as prophylactic gastric protection for use of some drugs, such as antimicrobials and nonsteroidal anti-inflammatory drugs. ${ }^{25-27}$ These off-label indications are for long-term use and are widespread and commonly prescribed in some countries, ${ }^{28}$ such as Brazil.

\section{OBJECTIVE}

The purpose of this review was to evaluate the adverse outcomes relating to omeprazole use in clinical practice.

\section{METHODS}

\section{Study design}

We conducted a qualitative narrative review with critical evaluation, to answer the following guiding question: "Which adverse events occur in patients using omeprazole in a Food and Drug Administration (FDA)-approved and/or off-label manner?" Thus, we aimed to gather, organize and critically review articles on these topics, to include the highest level of scientific evidence.

\section{Search of the literature and inclusion criteria}

The search for studies was performed using the MEDLINE (via PubMed), LILACS, EMBASE (via Ovid), SciELO and SCOPUS databases and was conducted on July 31, 2018. During the search and selection process, there was no limitation on the time when articles were published. The languages were restricted to Portuguese, English and Spanish.

The following search strategies were used: ("Omeprazole" OR "Proton Pump Inhibitors") AND (“Adverse Drug Reaction Reporting Systems" OR "Pharmacovigilance" OR "Drug-Related Side Effects and Adverse Reactions" OR "Risk Assessment” OR "Treatment Outcome" OR "Off-Label Use"). All descriptors used in these search strategies are Medical Subject Headings (MeSH terms). We included randomized clinical trials, phases I and II clinical trials, case-control studies, cohort studies, cross-sectional and quasi-experimental studies (clinical trials in which there was no comparator group for the intervention) evaluating adverse events from therapeutic or prophylactic use of omeprazole among individuals in all age groups whose health status was well defined and who were using omeprazole in an FDA-approved and/or off-label manner.

We excluded review articles, dissertations and theses, case reports, abstracts published in annals of events, editorials, letters to the editor, news and comments.

\section{Selection process and data extraction}

\section{Types of participant}

The target population comprised patients of any kind whose health status was well defined and who were using omeprazole in an FDA-approved and/or off-label manner. There was no age limitation.

\section{Types of intervention}

The interventions considered comprised use of omeprazole from the outset of treatment to clinical outcome, without restrictions on doses, therapeutic regimens or duration of use. In addition, it was proposed to include both preventive use and therapeutic use.

\section{Types of outcome}

The outcomes considered comprised any safety-related outcome, including adverse events, withdrawal due to adverse events, mortality and therapeutic ineffectiveness, i.e. adverse events in which the medicine used did not present any therapeutic response or its therapeutic response was lower than expected. Safety-related outcomes of all causes and omeprazole-related causes were considered.

After selecting potential articles in the databases, the titles and abstracts were reviewed by verifying patient exposure to omeprazole. The following variables were defined during the screening of articles: indication of use; study design; patient's clinical condition; clinical outcomes, including all types of adverse events relating to use of omeprazole; recommendations; author; and year of publication.

The severity of adverse events was classified as described by the World Health Organization. In this definition, severe adverse reactions are harmful effects that occur during drug treatment and which can result in death, be life-threatening or lead to persistent or significant disability, congenital anomaly, clinically important effects, hospitalization or prolongation of hospitalization. Non-serious adverse reactions also fall within the concept of severe adverse reactions. ${ }^{29}$

The search for studies, selection of studies and extraction of data were performed by three authors, in triplicate independently, to avoid the presence of bias in the selection and exclusion of articles. In addition, the kappa function was applied to analyze the agreement rate.

\section{Risk of bias assessment}

For randomized clinical trials, risk of bias was evaluated using the Cochrane collaboration tool (RoB 1), ${ }^{30}$ which is based on seven domains: random sequence generation, concealment of allocation, blinding of participants and professionals, blinding of outcome assessors, outcome completeness, selective reporting of outcomes and other sources of bias. Each domain is judged as presenting low risk of bias, uncertain risk of bias or high risk of bias.

For case-control and cohort studies, we used the Newcastle-Ottawa tool. This provides evaluations in three domains: selection, comparability and outcome for cohort studies; and selection, comparability and exposure for case-control studies. Each item that is identified as presenting low risk of bias is given a "star". There is a maximum of one "star" for each item within the "selection" and 
"exposure/outcome" categories; and a maximum of two "stars" for "comparability". Therefore, each study can be classified with a maximum of nine "stars", which corresponds to a low risk of bias. ${ }^{31}$

The cross-sectional and quasi-experimental studies included in this review were not evaluated, since there are no validated tools for analysis on these study designs.

\section{RESULTS}

A total of 5,500 potentially relevant studies were identified. After reading the titles and/or abstracts, 4,746 studies were excluded because they did not meet the inclusion criteria. Another 218 were duplicates, and thus 536 studies were examined further.

It was not possible to access 2 of these 546 studies, because one of them is no longer indexed in the database and the other does not provide for the option to purchase and access the article. Our attempts to contact the authors of these two studies were unsuccessful. After screening the remaining articles, 191 studies were found to be eligible for complete text reading. After reading in full, 119 were excluded because they did not meet the inclusion criteria. Thus, 72 articles were considered eligible for the safety assessment on use of omeprazole, since they included all the variables that were being analyzed (Figure 1).

The proportion of overall agreement (kappa) observed in relation to making final decisions (inclusion and exclusion) from the database that included the screened articles was 0.807 (confidence interval, CI: 0.658-0.957).

Among these 72 studies, 58 reported on adverse drug events (ADEs): 47 studies on adverse drug reactions (ADRs), 5 studies on drug interactions (DIs) and 6 studies on therapeutic ineffectiveness (Table 1). 13,14,32-48, 60, 65-67 The duration of use of omeprazole ranged from 5 days to 11 years in these studies. Only one study evaluated the off-label use of omeprazole. ${ }^{41}$

A relationship was observed between use of omeprazole and increased risk of severe adverse events, such as development of coronary disorders that might lead to death. ${ }^{32,39,43,62,88,94,96,101}$

Regarding the clinical outcomes of the studies, the safety (ADRs and DIs) and the therapeutic ineffectiveness can be correlated. Among the 62 studies included, 39 studies reported on ADRs, with 28 potential events that were identified during the post-marketing phase in relation to omeprazole (spontaneous abortion, proliferative changes and chills, among others); 6 studies demonstrated the drug interactions between omeprazole and clopidogrel or mycophenolate mofetil; and 5 studies described the therapeutic ineffectiveness that occurred with omeprazole (Table 2). 5,13,16,32-34,38-39,40-42,44-99

Among the 40 clinical trials included in the review, after riskof-bias analysis, it was found that eight were classified as presenting low risk of bias, 14 as having high risk of bias and 17 as having uncertain risk of bias. The 17 studies analyzed using the Newcastle-Ottawa scale had low risk of bias (Table 3)..$^{13,16,28,32,33,35-39,43-97}$

\section{DISCUSSION}

This review allowed us to identify and update the most severe and prevalent ADEs relating to use of omeprazole, and our findings corroborate similar results found in other studies. ${ }^{3,4}$ Severe ADEs occurred in patients who underwent heart-related surgery or drug interventions, such as in situations of acute coronary syndromes or percutaneous coronary intervention, ${ }^{75,78,96}$ or in cases of concomitant use of such medications. ${ }^{76}$ These events were associated with concomitant use of omeprazole and clopidogrel, which caused inhibition of the antiplatelet effect of omeprazole, ${ }^{83}$ due to competitive inhibition of CYP2C19. ${ }^{32}$

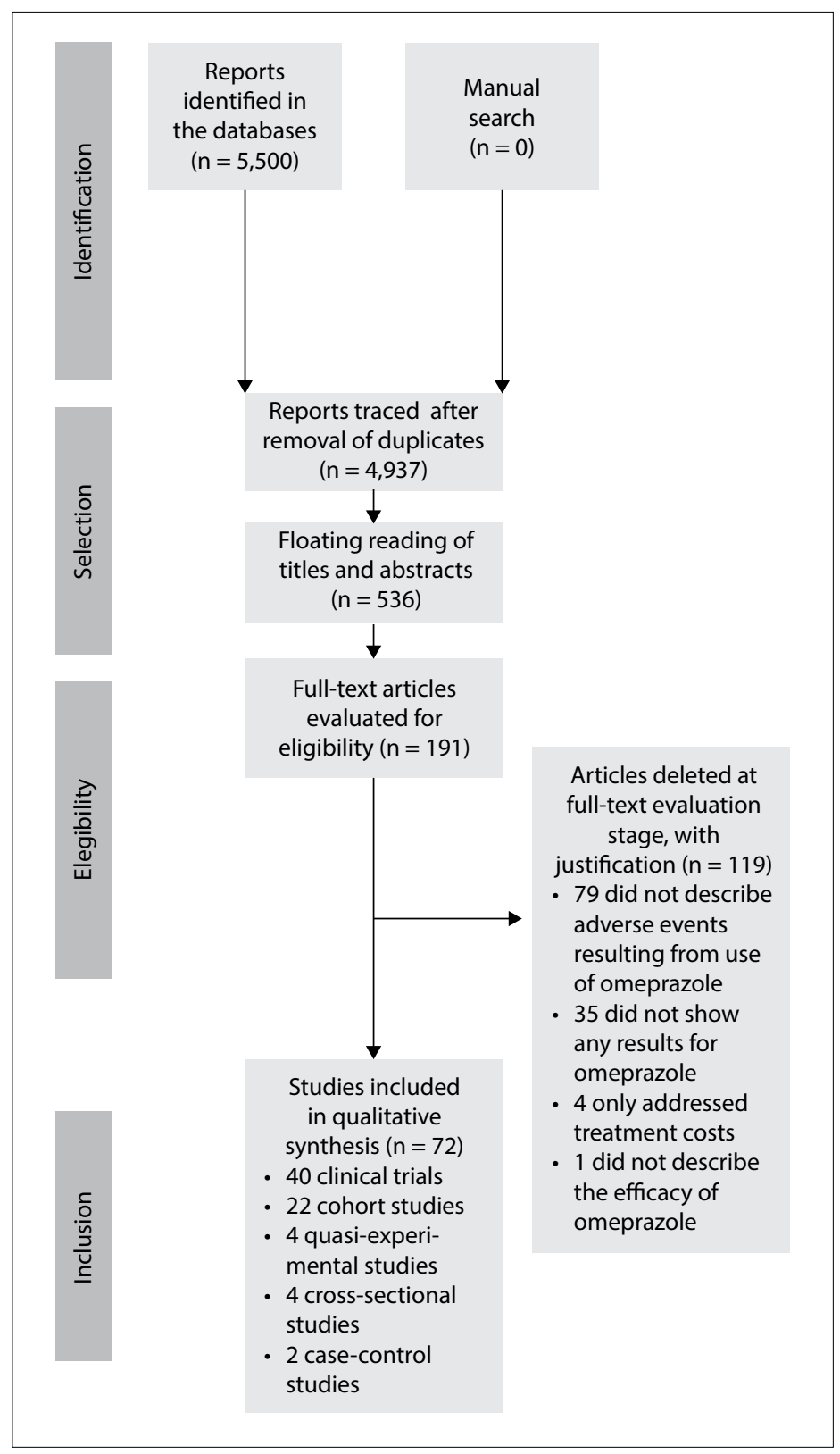

Figure 1. Flowchart of the stages of selection, skim-reading and full reading of the eligible articles. 
Table 1. Frequencies of adverse events resulting from indication of omeprazole that were reported in studies published up to 2016

\begin{tabular}{|c|c|c|c|}
\hline Assessment & Type of ADE & Frequency & Description \\
\hline \multirow[b]{5}{*}{ Safety } & \multirow{5}{*}{$\begin{array}{c}\text { ADR } \\
(n=47)\end{array}$} & $\begin{array}{l}\text { Common reaction } \\
(\geq 1 \% \text { and }<10 \%)\end{array}$ & $\begin{array}{l}\text { Headache, constipation, diarrhea, abdominal pain, back pain, flatulence, respiratory tract } \\
\text { infection and maculopapular rash. }{ }^{32-37}\end{array}$ \\
\hline & & $\begin{array}{l}\text { Uncommon reaction } \\
(\geq 0.1 \% \text { and }<1 \%)\end{array}$ & Eczematous eruption, insomnia, somnolence, urticaria, urticaria vasculitis and vertigo. ${ }^{38}$ \\
\hline & & $\begin{array}{c}\text { Rare reaction } \\
(\geq 0.01 \% \text { and }<0.1 \%)\end{array}$ & $\begin{array}{l}\text { Angioedema, arthralgia, muscle pain, erythema multiforme, weakness, metallic taste in the } \\
\text { mouth, allergic reaction, Steven-Johnson's syndrome and thirst. }{ }^{38}\end{array}$ \\
\hline & & $\begin{array}{l}\text { Post-marketing } \\
\text { experience }\end{array}$ & $\begin{array}{l}\text { Unstable angina, increased risk of fractures, cancer, cystitis, ulcerative colitis, stomatitis, } \\
\text { abnormal renal function, hypergastrinemia, decreased levels of vitamin B12, increased } \\
\text { creatinine levels, hypomagnesemia. } .^{14,39-43}\end{array}$ \\
\hline & & $\begin{array}{l}\text { Potential events } \\
\text { not described } \\
\text { in omeprazole } \\
\text { monograph } \\
(n=28)\end{array}$ & $\begin{array}{l}\text { Miscarriage, proliferative changes, increased levels of chromogranin A, increased levels of } \\
\text { fibroblast growth factor } 2 \text {, chills, cardiovascular events (myocardial infarction, heart failure, } \\
\text { stroke, ischemic stroke, pulmonary embolism and thrombosis), scarlet fever, hyperglycemia, } \\
\text { mononucleosis infection, gastrointestinal bleeding, nasopharyngitis, otitis media, loss of } \\
\text { libido, rhinitis, dementia, metabolic syndrome and hepatic steatosis, low sperm motility, } \\
\text { increased risk of fibrosis progression, cirrhosis, hepatic decompensation and development of } \\
\text { hepatocellular carcinoma. }{ }^{44-48,60,65-67}\end{array}$ \\
\hline Efficacy & $\mathrm{TI}(\mathrm{n}=5)$ & \multicolumn{2}{|c|}{$\begin{array}{l}\text { Some patients did not respond to omeprazole therapy and continued with colitis symptoms and gastrointestinal } \\
\text { discomforts. Omeprazole failed to control the gastric acidity of some patients. }{ }^{13}\end{array}$} \\
\hline
\end{tabular}

$\mathrm{ADE}=$ adverse drug event; $\mathrm{ADR}=$ adverse drug reaction; $\mathrm{DI}$ = drug interaction; $\mathrm{Tl}$ = therapeutic ineffectiveness.

The frequency of adverse reactions was classified according to the leaflet of the reference drug product, except for the 28 studies for which there was no information on the leaflet.

Table 2. Adverse events from approved use of omeprazole that were reported in the studies analyzed, published from 1994 to July 2018

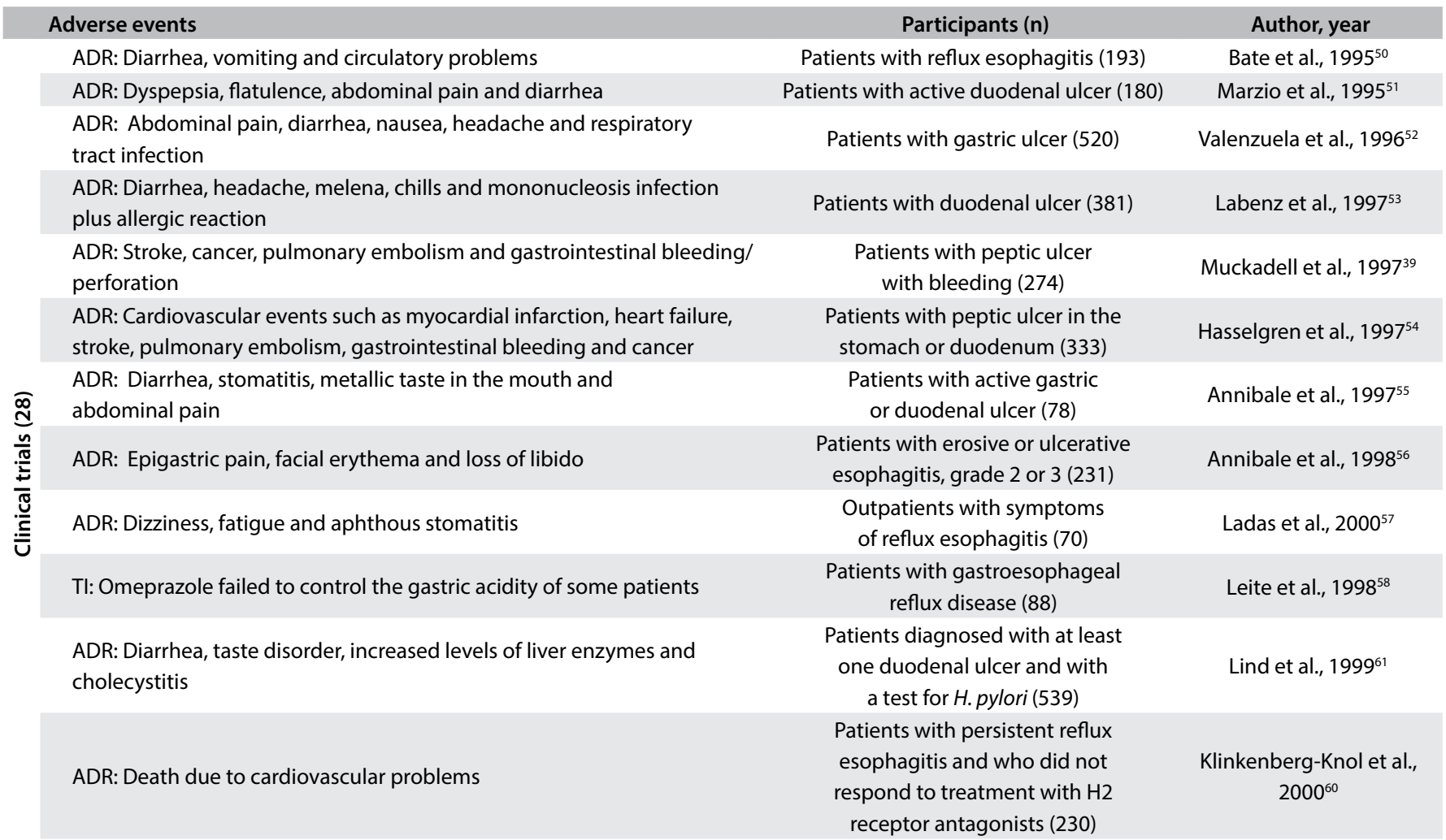

ADR: Diarrhea, nausea, headache, cold, vomiting and fever

Patients with gastroesophageal reflux without erosive esophagitis (359)

Richter et al., $2000^{59}$ 
Table 2. Continuation

\section{Adverse events}

TI/ADR: Worsening of symptoms; taste disorder and scarlet fever

ADR: Diarrhea, pericarditis and chest pain

ADR: Diarrhea, abdominal pain and headache

TI: Some patients did not respond to treatment with omeprazole

ADR: Increased fibroblast growth factor 2

ADR: Myocardial infarction, ventral hernia, deep vein thrombosis, miscarriage, headache, respiratory infection, diarrhea and abdominal pain

ADR: Diarrhea, taste disorders and dyspepsia

ADR: Nasopharyngitis, upper respiratory tract inflammation, diarrhea,

headache, arthralgia, back pain, insomnia, cystitis, abdominal pain and hyperglycemia

ADR: Allergic reaction

ADR/TI: Headache, somnolence and diarrhea

ADR: Headache and gastrointestinal disorders

ADR: Increased weight, increased ferritin level, increased death related to cardiac disorders and non-fatal heart attack

ADR: Omeprazole reduced antiplatelet effects

DI: Increased levels of leukocytes and platelets and increased incidence

of cardiac and cerebral adverse events

ADR: Diarrhea, tiredness, dizziness, abdominal pain and headache

ADR: Thrombosis, hyperthyroidism, complete retinal detachment, ulcerative colitis and skin rash

ADR: Death due to cardiovascular, cerebrovascular, respiratory and postoperative problems, carcinomas, urinary tract infections and suicide

ADR: Myocardial infarction, stroke, cardiovascular death and unstable angina

DI: Inhibition of the effect of clopidogrel

DI: Increased anticoagulant effect of acenocoumarol

TI: Cardiovascular death, myocardial infarction and stroke

ADR: Increased levels of chromogranin A

ADR: Hypergastrinemia

TI: Omeprazole failed to control the gastric acidity of some patients

DI: Inhibition of the effect of clopidogrel

ADR: Increased risk of fractures

ADR: Increased risk of dementia

ADR: Increased risk of first-time ischemic stroke

ADR: Increased serum creatinine levels

ADR: Increased risk of metabolic syndrome and hepatic steatosis

ADR: Hypomagnesemia

ADR: Increased risk of fibrosis progression, cirrhosis, hepatic decompensation and development of hepatocellular carcinoma
Participants (n)

Author, year

Patients with chronic functional

dyspepsia with or without gastritis due to H. pylori (974)

Patients with erosive gastroesophageal reflux cured within 90 days (243)

Patients with dyspeptic symptoms (73) Patients with dyspepsia (514)

Patients with gastric neoplasm (16) Patients who suffered with burning in the stomach for at least three months (390) Patients infected with $\mathrm{H}$. pylori with abdominal disorders (323) Blum et al., $2000^{62}$

Thjodleifsson et al., 200063

Gottrand et al., $2001^{33}$

Rabeneck et al., $2002^{64}$

Esaki et al., 200265

Japanese patients with recurrent reflux esophagitis (119)

Patients with lymphocytic gastritis (51)

HIV-negative, healthy patients (19)

Patients with burning in the stomach or reflux (55)

Patients with esophageal reflux (310)

Unmedicated male patients (24)

Armstrong et al., $2005^{66}$

Manes et al., $2005^{38}$

Ohkusa et al., $2005^{67}$

Madisch et al., $2006^{68}$

Schöller-Gyüre et al., $2008^{32}$

Howden et al., $2009^{69}$

Lundell et al., $2009^{70}$

Ferreiro et al., $2010^{71}$

Patients with stent implantation (38)

Hudzik et al., $2010^{72}$

Patients with typical symptoms of reflux more than twice a week (200)

Miwa et al., $2011^{73}$

Patients with persistent reflux esophagitis and who did not respond to treatment with $\mathrm{H}_{2}$ receptor antagonists (178)

Diagnosed with colitis due to C. difficile (140) Patients using clopidogrel after percutaneous coronary intervention $(16,690)$

Patients using clopidogrel $(18,139)$ Patients that used acenocoumarol for at least 42 days in the study period $(2,755)$

Patients who underwent coronary intervention $(13,144)$

Patients with increased levels of

chromogranin A that could not be caused by neuroendocrine tumors (196) Patients with moderate to severe peptic esophagitis Patients who underwent kidney transplantation

Patients with acute coronary syndrome $(37,099)$ Patients who underwent medical consultations in the last two years $(61,916)$

Elderly people over 75 years old $(73,679)$ $-(396,296)$

Inpatient patients (419)

Patients with a recent diagnosis of celiac disease (301) Hospitalized patients with Torsades de pointes (48) Patients with hepatitis $C$ virus (HCV) infection.
Klinkenberg-Knol et al., $1994^{74}$

Cadle et al., $2007^{13}$

Kreutz et al., $2010^{75}$

van Boxel et al., $2010^{76}$

Teichert et al., $2011^{77}$

Kimura et al., $2011^{78}$

Korse et al., $2011^{79}$

Ligumsky et al., $2011^{80}$

David-Neto et al., $2012^{49}$

Lin et al., $2012^{8}$

Soriano et al., $2014^{16}$

Gomm et al, 2016

Yi et al., $2017^{47}$

Varallo et al., 2018 ${ }^{41}$

Imperatore et al., $2018^{45}$

Lazzerini et al., $2018^{42}$

Li et al., $2018^{48}$ 
Table 2. Continuation

\section{Adverse events}

Participants (n)

Author, year

Patients with burning in the

ADR: Diarrhea and ringing in the ears stomach, erosive esophagitis or non-erosive reflux disease (108)

ADR: Respiratory infection, otitis media, pharyngitis, change in bowel habit, fever and rhinitis

Patients with cured reflux esophagitis (64)

ADR: Nausea, vomiting, constipation, diarrhea, metallic taste in the mouth, headache, abdominal pain, loss of appetite, drowsiness, weakness, dizziness and dry mouth

ADR: Myocardial infarction or heart failure with or without consequent death

Patients with H. pylori (134)

Sezgin et al., $2014^{34}$

Patients who were hospitalized due to myocardial infarction within

12 weeks after starting use of

Juurlink et al., $2013^{84}$

proton-pump inhibitors $(5,550)$

Patients with dyspepsia,

ADR: Maculopapular rash, angioedema and/or urticaria,

Steven-Johnson's syndrome, erythema multiforme, eczematous eruption and urticarial vasculitis gastroesophageal reflux disease and upper gastrointestinal tract bleeding; prevention of ulcers induced by

Chularojanamontri et al., onsteroidal anti-inflammatory drugs,

$2012^{85}$ stress and prednisolone (170)

Men who were planning to have children (955)

Heijgen et al., $2016^{46}$

ADR: Low sperm motility

Patients who underwent endoscopy

ADR: Proliferative changes and who had been using proton-pump

Menegassi et al., $2010^{5}$ inhibitors for at least 2 months (22)

Patients with diagnosis of

ADR: Decreased serum levels of vitamin B12 gastrointestinal disease in the consumption of proton

Mindiola et al., $2017^{40}$

Tsuzuki et al., $2011^{82}$

Hassall et al., $2012^{83}$

Yamamoto et al., $1995^{86}$ Goh et al., $1995^{87}$; Soga et al., 199937; Noordzij et al., 200188; Zhou et al., 2002 ${ }^{43}$;

Clinical trials (12)

Many conditions van Zanten et al., $2005^{35}$. Fujiwara et al., 2005 ${ }^{89}$; Liu et al., 201390; Miner JR et al., 201091; Ummarino et al., 201236; Sakurada et al., 2012 $2^{92}$; Solana et al., $2013^{93}$

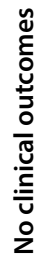

Cohort studies (5)

Many conditions

Newborns with hypospadias born to mothers who had used proton-pump inhibitors during pregnancy $(430,569)$

Cross-sectional studies (2)

Patients with stage 5 chronic kidney disease (CKD) on hemodialysis therapy and chronic use of proton pump inhibitors (37)
Erichsen et al., 2014 $4^{98}$

Zairis et al., 201094; Harjai et al., 201195; Chen et al., 2014 ${ }^{28}$; Galante et al., 2012 ${ }^{96}$; Wang et al., $2017^{97}$

Restrepo et al., $2017^{99}$

$\mathrm{ADE}=$ adverse drug event; $\mathrm{ADR}=$ adverse drug reaction; $\mathrm{DI}=$ drug interaction; $\mathrm{TI}=$ therapeutic ineffectiveness. 
Table 3. Assessment of risk of bias in clinical trials using the RoB 1.0 tool and evaluation of quality of cohort and control case studies using the Newcastle-Ottawa scale

\begin{tabular}{|c|c|c|c|c|c|c|c|c|}
\hline \multirow{2}{*}{ 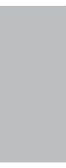 } & \multirow{2}{*}{ Study } & \multicolumn{7}{|c|}{ Risk of bias } \\
\hline & & $\begin{array}{c}\text { Random } \\
\text { sequence } \\
\text { generation }\end{array}$ & $\begin{array}{l}\text { Allocation } \\
\text { concealment }\end{array}$ & $\begin{array}{l}\text { Blinding of } \\
\text { participants } \\
\text { and personnel }\end{array}$ & $\begin{array}{l}\text { Blinding of } \\
\text { outcome } \\
\text { assessors }\end{array}$ & $\begin{array}{l}\text { Incomplete } \\
\text { outcome data }\end{array}$ & $\begin{array}{l}\text { Selective } \\
\text { outcome } \\
\text { reporting }\end{array}$ & $\begin{array}{c}\text { Other } \\
\text { sources of } \\
\text { bias }\end{array}$ \\
\hline \multirow{30}{*}{ 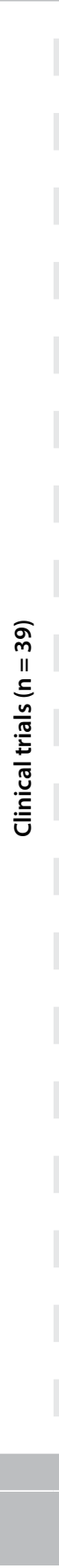 } & Bate et al., $1995^{50}$ & Unclear & Unclear & Low & Low & Low & Low & Low \\
\hline & Goh et al., $1995^{87}$ & Unclear & Unclear & Unclear & Low & Unclear & Low & Low \\
\hline & Valenzuela et al., $1996^{52}$ & Unclear & Unclear & Low & Low & Low & Low & Low \\
\hline & Muckadell et al., $1997^{39}$ & Low & Low & Low & Low & Low & Low & Low \\
\hline & Labenz et al., $1997^{53}$ & Low & Unclear & Low & Low & Low & Low & Low \\
\hline & Annibale et al., $1997^{55}$ & Unclear & Unclear & Low & Low & Low & Low & Low \\
\hline & Hasselgren et al., $1997^{54}$ & Unclear & Low & Low & Low & Low & Low & Low \\
\hline & Ladas et al., $2000^{57}$ & Low & High & Low & High & Low & Low & Low \\
\hline & Richter et al., $2000^{59}$ & Unclear & Unclear & Low & Unclear & Low & Low & Low \\
\hline & Blum et al., $2000^{62}$ & Unclear & Low & Low & Low & Low & Low & Low \\
\hline & Noordzij et al., $2011^{88}$ & Unclear & Low & Low & Low & Low & Low & Low \\
\hline & Gottrand et al., $2001^{33}$ & Low & Low & Low & Low & Low & Low & Low \\
\hline & Esaki et al., $2002^{65}$ & Unclear & Unclear & Low & Low & Low & Low & Low \\
\hline & Rabeneck et al., $2002^{64}$ & Low & Low & Low & Low & Low & Low & Low \\
\hline & Zhou et al., $2002^{43}$ & Unclear & Unclear & High & High & Low & Low & Low \\
\hline & Thjodleifsson et al., $2000^{63}$ & Low & Low & Low & Low & Low & Low & Low \\
\hline & Armstrong et al., $2005^{66}$ & Low & Low & Low & Low & Low & Low & Low \\
\hline & Howden et al., $2009^{69}$ & Unclear & Unclear & Unclear & High & Low & Low & Low \\
\hline & Lundell et al., $2009^{70}$ & Unclear & Unclear & Low & Unclear & Low & Low & Low \\
\hline & Miner et al., $2010^{91}$ & Low & Low & Low & Low & Low & Low & Low \\
\hline & Hudzik et al., $2010^{72}$ & High & High & Low & High & Low & Low & Low \\
\hline & Ferreiro et al., $2010^{71}$ & Unclear & Unclear & Low & Low & Low & Low & Low \\
\hline & Miwa et al., $2011^{73}$ & Low & Low & Low & Low & Low & Low & Low \\
\hline & Sakurada et al., $2012^{92}$ & Unclear & Low & Low & High & Low & Low & Low \\
\hline & Ummarino et al., $2011^{36}$ & Unclear & Unclear & Unclear & Unclear & Low & Low & Low \\
\hline & Liu et al., $2013^{90}$ & Low & Unclear & Low & High & Low & Low & Low \\
\hline & Solana et al., $2013^{93}$ & Low & Unclear & Unclear & Unclear & Low & Low & Low \\
\hline & \multicolumn{8}{|c|}{ Evaluation of quality of cohort and control case studies using the Newcastle-Ottawa scale } \\
\hline & \multirow{2}{*}{ Study } & \multicolumn{7}{|c|}{ Domains } \\
\hline & & \multicolumn{3}{|c|}{ Selection $\left(4^{*}\right)$} & \multicolumn{2}{|c|}{ Comparability $\left(2^{*}\right)$} & \multicolumn{2}{|c|}{ Outcome $\left(3^{*}\right)$} \\
\hline \multirow{5}{*}{ 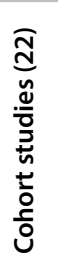 } & \multicolumn{2}{|l|}{ Klinkenberg-Knol et al., $1994^{74}$} & \multicolumn{2}{|l|}{$4^{*}$} & \multicolumn{2}{|c|}{$1^{*}$} & \multicolumn{2}{|c|}{$3^{*}$} \\
\hline & \multicolumn{2}{|l|}{ Kreutz et al., $2010^{75}$} & \multicolumn{2}{|l|}{$4^{*}$} & \multicolumn{2}{|l|}{$2^{*}$} & \multicolumn{2}{|l|}{$3^{*}$} \\
\hline & \multicolumn{2}{|l|}{ Van Boxel et al., $2010^{76}$} & $4^{*}$ & & $2^{*}$ & & $3^{*}$ & \\
\hline & Zairis et al., $2010^{94}$ & & $4^{*}$ & & $2^{*}$ & & $3^{*}$ & \\
\hline & Cadle et al., $2007^{13}$ & & $4^{*}$ & & $2^{*}$ & & $3^{*}$ & \\
\hline
\end{tabular}


Table 3. Continuation

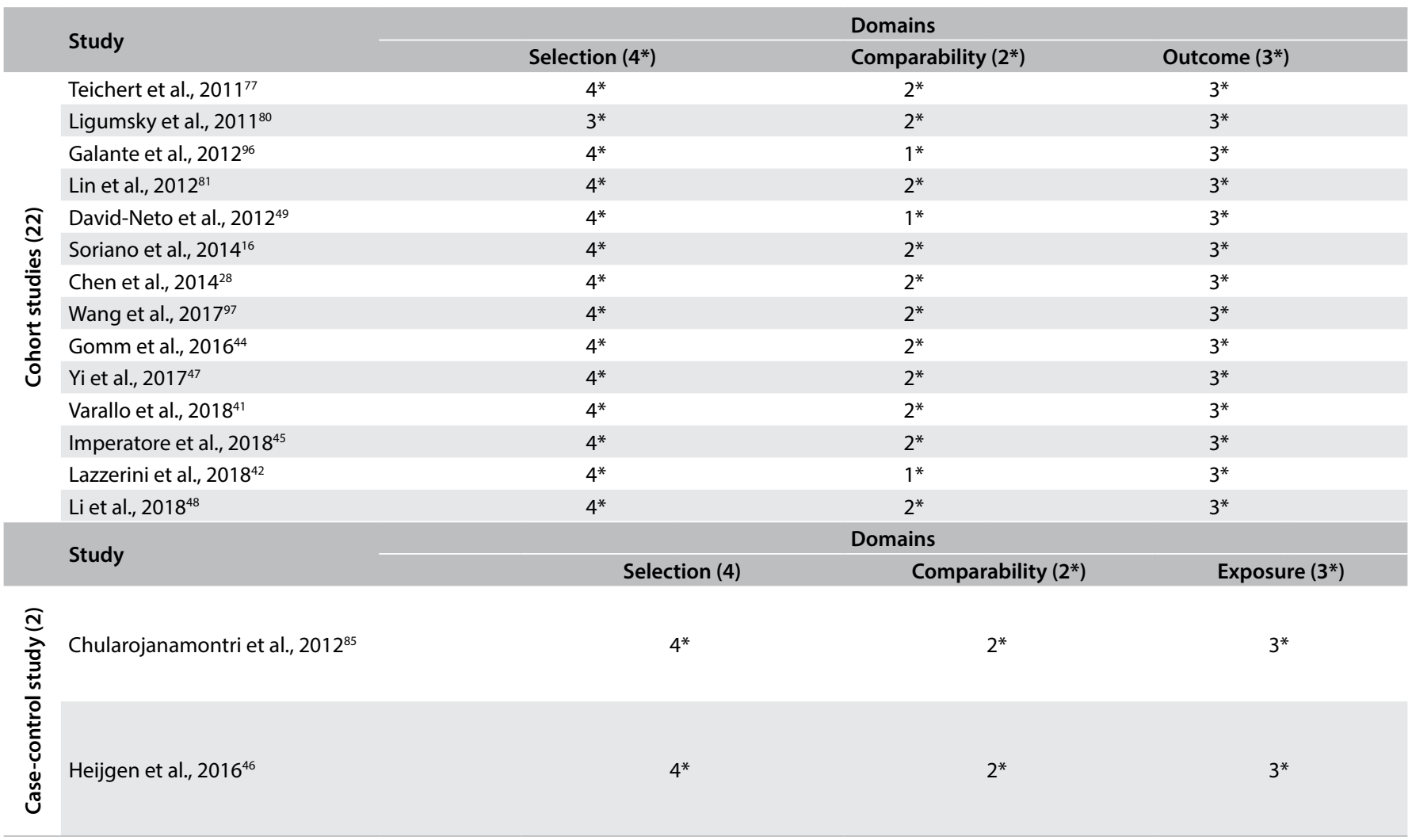

Several drug interactions relating to omeprazole, especially with antiplatelet agents, are known. ${ }^{78,94}$ The non-serious events that have been described are diarrhea, headache and somnolence, relating to use of omeprazole concomitantly with the antiretroviral drug etravirine. ${ }^{32}$ The severe adverse events that have been described comprise inhibition of the antiplatelet effects of drugs such as clopidogrel, which increases the risk of developing heart problems that may lead to death; and decreased absorption of mycophenolic acid, which leads to rejection of transplanted organs. ${ }^{49}$

Nevertheless, it is not possible to say with certainty that the adverse events described in these studies occurred due to drug interactions with omeprazole, since some of the studies included did not present statistically significant results. ${ }^{71,94-96}$

In two studies in which omeprazole was added to dual antiplatelet therapy (a combination of clopidogrel and acetylsalicylic acid), it reduced the stomach pain resulting from this therapy and no risk was found in this combination. ${ }^{95}$ Nonetheless, it is always necessary to monitor potentially dangerous drug combinations between omeprazole and clopidogrel, acetylsalicylic acid and mycophenolate mofetil, among others.

Regarding drug interactions, all patients may be exposed to their effects, regardless of age or clinical condition. However, some patients are more susceptible, such as those who already have some type of heart disease or the elderly, who commonly use polypharmacy.

Only 12 studies included elderly patients, and these studies reported occurrences of severe adverse events such as dementia, myocardial infarction, cardiovascular death, stroke and pulmonary embolism, among others. In the non-elderly population, the severe adverse events reported included myocardial infarction, stroke, death and pulmonary embolism, but no relationship between the severity or the frequency of events and the patients' age was observed from use of omeprazole. However, other authors have suggested that age is a factor that influences occurrences of adverse events. Varallo et al. ${ }^{24}$ observed in a cross-sectional study that the elderly population had fewer ADEs than adults did, probably because doctors provide greater care and attention regarding pharmacotherapeutic management for patients of this age group, since there are other factors that increase the likelihood of ADEs, such as polypharmacy. Beijer and de Blaey ${ }^{100}$ reported that the chances that elderly individuals would need to be hospitalized due to adverse drug reactions (ADRs) were four times higher than those of younger people ( $16.6 \%$ versus $4.1 \%)$. Additionally, in 2015, the American Geriatrics Society advised through the Beers criteria that unjustified use of PPIs among the elderly for more than eight weeks should be avoided, since exposure to 
such drugs increases the risks of infection by Clostridium difficile, bone loss and fractures. ${ }^{13,16,101}$

Another factor that may have influenced the appearance of adverse events is the duration of use of omeprazole. Non-serious adverse events such as diarrhea, headache, flatulence and abdominal pain, among others, have been reported among patients taking omeprazole for short periods of time, i.e. from a few days of use to a maximum of two weeks. ${ }^{32-36,74}$ Severe adverse events have been reported among patients who used omeprazole for longer

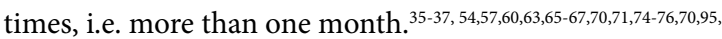

In only one of the studies analyzed here was omeprazole prescribed for off-label use. ${ }^{41}$ However, off-label prescription of omeprazole is widespread in many countries and there is a need to assess the safety of this use. We take the view that the duration of exposure is likely to increase the likelihood of adverse events, since polypharmacy alone is a risk factor for occurrences of adverse events. ${ }^{24}$

Outcomes of therapeutic ineffectiveness and symptom worsening were identified. It was noted that some patients did not respond to omeprazole treatment ${ }^{13,32,64,70}$ and that for others, their symptoms worsened. ${ }^{62}$ The most likely reason for such events would be high concentrations of acid in the stomach, which could cause gastroparesis, decrease absorption and, consequently, decrease the therapeutic effect of omeprazole.

Although most of the adverse events reported were already known, unexpected events such as dementia, ${ }^{44}$ low-motility sperm, ${ }^{46}$ miscarriage, proliferative changes, ${ }^{5}$ increased levels of chromogranin $\mathrm{A},{ }^{79}$ increased levels of fibroblast growth factor $2,{ }^{72}$ chills, cardiovascular events (myocardial infarction, heart failure, stroke, ischemic stroke, pulmonary embolism and thrombosis), ${ }^{47}$ scarlet fever, hyperglycemia, mononucleosis infection, gastrointestinal bleeding, nasopharyngitis, otitis media, loss of libido and rhinitis have also been identified. ${ }^{4,65-67,102}$ Because the associations between these adverse events and use of omeprazole are not fully understood, there is a need to carry out further studies to investigate the relationships between omeprazole and these events. If such associations are verified, they should be described in the package leaflet.

In addition, more recent studies have identified other adverse events, such as decreased vitamin B12 levels, ${ }^{40}$ increased levels of creatinine $^{41}$ and hypomagnesia. ${ }^{42}$

Use of omeprazole is considered safe in the following situations: when it is not combined with antiplatelet drugs; when it is administered to replace $\mathrm{H} 2$ receptor antagonists in patients who are resistant to treatment with drugs of this class; when the most appropriate posology and dosage is established for each condition and patient; and when omeprazole is used in conjunction with a combination of antibiotics to eradicate $H$. pylori and to treat esophagitis, among

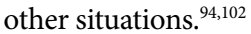

\section{Limitations of the present study}

No a priori design was provided for this review and the languages were restricted to Portuguese, English and Spanish.

Gray literature was not included. However, its inclusion would be unviable and probably would not add to the results found, since this type of literature is characterized by incomplete and poorly constructed data.

No methods were used to assess the homogeneity or heterogeneity between the studies, and the risk of publication bias among the studies included was not assessed. Furthermore, no information regarding potential conflicts of interest in the primary studies included was available.

All the outcomes evaluated related to approved indications for use of omeprazole. Therefore, the data confirm that there is no evidence of clinical outcomes (safety and effectiveness) resulting from unapproved use of omeprazole, such as polypharmacy (although polypharmacy is commonly used). The duration of use of omeprazole influenced occurrences of adverse events. Severe adverse events, such as death, stroke and myocardial infarctions occurred during prolonged treatments (more than one month). Non-serious adverse events occurred over short periods (from a few days to a maximum of two weeks). Use of omeprazole needs to be monitored primarily in patients with heart disorders who are using antiplatelet agents and omeprazole concomitantly and in newly transplanted patients who are using mycophenolic acid as a suppressive agent, in order to avoid severe adverse reactions such as organ transplant rejection, death, stroke and myocardial infarction.

\section{CONCLUSION}

Therefore, use of omeprazole can be considered safe in the following situations: when it is not combined with antiplatelet drugs; when it is administered to replace $\mathrm{H} 2$ receptor antagonists in patients who are resistant to treatment with drugs of this class; when the posology is well established for each condition and type of patient; and when omeprazole is used to eradicate $H$. pylori, among others. Most of the trials included in this review presented uncertain risk or high risk of bias, which indicates that there is a need for betterdesigned studies. The high risk of bias related mainly to the blinding of the participants and outcome assessors. It should be noted that if patients and professionals believe that omeprazole is a gastric protector and is risk-free, this may lead to bias in the analysis and to under identification and underreporting of adverse events relating to omeprazole. This may suggest that the existing studies may have underestimated the adverse events.

\section{REFERENCES}

1. Li W, Zeng S, Yu LS, Zhou Q. Pharmacokinetic drug interaction profile of omeprazole with adverse consequences and clinical risk management. Ther Clin Risk Manag. 2013;9:259-71. PMID: 23745048; doi: 10.2147/TCRM.S43151. 
2. Johnson DA, Oldfield EC 4th. Reported side effects and complications of long-term proton pump inhibitor use: dissecting the evidence. Clin Gastroenterol Hepatol. 2013;11(5):458-64; quiz e37-8. PMID: 23247326; doi: 10.1016/j.cgh.2012.11.031.

3. Mastroianni PC, Varallo FR, Barg MS, Noto AR, Galduróz JCF. Contribuição do uso de medicamentos para a admissão hospitalar. Braz J Pharm Sci. 2009;45(1):163-70. doi: 10.1590/S1984-82502009000100020.

4. Rodrigues Abjaude SA, de Carvalho Mastroianni P. Uso profilático de omeprazol: qual é o risco/benefício? Rev OFIL. 2015;26(2):142-5. Available from: http://www.revistadelaofil.org/carta-al-director-usoprofilatico-omeprazol-qual-e-riscobeneficio/. Accessed in 2018 (Mar 22).

5. Menegassi VS, Czeczko LEA, Czeczko LSG, et al. Prevalência de alterações proliferativas gástricas em pacientes com uso crônico de inibidores de bomba de próton [Prevalence of gastric proliferative changes in patients with chronic use of proton pump inhibitor agents]. ABCD, Arq Bras Cir Dig. 2010;23(3):145-9. doi: 10.1590/\$0102-67202010000300003.

6. Härmark L, van der Wiel HE, de Groot MC, van Grootheest AC. Proton pump inhibitor-induced acute interstitial nephritis. Br J Clin Pharmacol. 2007;64(6):819-23. PMID: 17635502; doi: 10.1111/j.13652125.2007.02927.x.

7. Australian Government Department of Health and Ageing - Therapeutic Goods Administration Adverse Drug Reactions Advisory Committee (ADRAC). Australian Adverse Drug Reactions Bulletin. Aust Advers Drug React Bull [Internet]. 2007;26(1):2-3. Available from: https://www.tga. gov.au/sites/default/files/aadrb-0702.pdf. Accessed in 2018 (Mar 22).

8. Myers RP, McLaughlin K, Hollomby DJ. Acute interstitial nephritis due to omeprazole. Am J Gastroenterol. 2001;96(12):3428-31. PMID: 11774962; doi: 10.1111/j.1572-0241.2001.05345.x.

9. Xie Y, Bowe B, Li T, et al. Long-term kidney outcomes among users of proton pump inhibitors without intervening acute kidney injury. Kidney Int. 2017;91 (6):1482-94. PMID: 28237709; doi: 10.1016/j.kint.2016.12.021.

10. Harding SM, Richter JE, Guzzo MR, et al. Asthma and gastroesophageal reflux: Acid suppressive therapy improves asthma outcome. Am J Med. 1996;100(4):395-405. PMID: 8610725; doi: 10.1016/S00029343(97)89514-9.

11. Stevens V, Dumyati G, Brown J, Wijngaarden E. Differential risk of Clostridium difficile infection with proton pump inhibitor use by level of antibiotic exposure. Pharmacoepidemiol Drug Saf. 2011;20(10):1035-42. PMID: 21833992; doi: 10.1002/pds.2198.

12. Linsky A, Gupta K, Lawler E V., Fonda JR, Hermos JA. Proton pump inhibitors and risk for recurrent clostridium difficile infection. Arch Intern Med. 2010;170(9):772-8. PMID: 20458084; doi: 10.1001/ archinternmed.2010.73.

13. Cadle RM, Mansouri MD, Logan N, Kudva DR, Musher DM. Association of proton-pump inhibitors with outcomes in Clostridium difficile colitis. Am J Health Syst Pharm. 2007;64(22):2359-63. PMID: 17989446; doi: 10.2146/ajhp060629.

14. Proesmans M, De Boeck K. Omeprazole, a proton pump inhibitor, improves residual steatorrhoea in cystic fibrosis patients treated with high dose pancreatic enzymes. Eur J Pediatr. 2003;162(11):760-3. PMID: 13680386; doi: 10.1007/s00431-003-1309-5.

15. Fraser L, LeslieWD, Targownik LE, Papaioannou A, Adachi JD. The effect of proton pump inhibitors on fracture risk: report from the Canadian Multicenter Osteoporosis Study. Osteoporos Int. 2013;24(4):1161-8. PMID: 22890365; doi: 10.1007/s00198-012-2112-9.

16. Cea Soriano L, Ruigómez A, Johansson S, García Rodríguez LA. Study of the association between hip fracture and acid-suppressive drug use in a UK primary care setting. Pharmacotherapy. 2014;34(6):570-81. PMID: 24634193; doi: 10.1002/phar.1410.

17. Carvajal A, Macias D, Gutiérrez A, et al. Gynaecomastia associated with proton pump inhibitors: A case series from the Spanish pharmacovigilance system. Drug Saf. 2007;30(6):527-31. PMID: 17536878.

18. Rodriguez LAG, Ruigómez A, Wallander MA, Johansson S. Acidsuppressive drugs and community-acquired pneumonia. Epidemiology. 2009;20(6):800-6. PMID: 19797970; doi: 10.1097/ EDE.0b013e3181b5f27d.

19. Buon M, Gaillard C, Martin J, et al. Risk of proton pump inhibitor-induced mild hyponatremia in older adults. J Am Geriatr Soc. 2013;61(11):2052-4. PMID: 24219214; doi: 10.1111/jgs.12534.

20. Bajaj JS, Zadvornova Y, Heuman DM, et al. Association of proton pump inhibitor therapy with spontaneous bacterial peritonitis in cirrhotic patients with ascites. Am J Gastroenterol. 2009;104(5):1130-4. PMID: 19337238; doi: 10.1038/ajg.2009.80.

21. Ramírez E, Cabañas R, Laserna LS, et al. Proton pump inhibitors are associated with hypersensitivity reactions to drugs in hospitalized patients: a nested case-control in a retrospective cohort study. Clin Exp Allergy. 2013;43(3):344-52. PMID: 23414543; doi: 10.1111/ cea.12034.

22. Lebwohl B, Spechler SJ, Wang TC, Green PHR, Ludvigsson JF. Use of proton pump inhibitors and subsequent risk of celiac disease. Dig Liver Dis. 2014;46(1):36-40. PMID: 24035759; doi: 10.1016/j.dld.2013.08.128.

23. Mastroianni C, Varallo FR, Carradore MD. Apêndice: Informações específicas dos fármacos a ser orientadas na dispensação. In: Mastroianni C, Varallo FR, Carradore MD, editores. Dispensação de Medicamentos Essenciais de Uso Ambulatorial: Orientações para uso correto. São Paulo: Cultura Acadêmica; 2010. p. 60-70. ISBN 97885-7983-273-4.

24. Varallo FR, Oliveira FM, Mastroianni PC. Safety assessment of essential medicines for elderly people: A bibliographic survey. Braz J Pharm Sci. 2014;50(2):269-84. doi: 10.1590/S1984-82502014000200006.

25. Pham CQ, Regal RE, Bostwick TR, Knauf KS. Acid suppressive therapy use on an inpatient internal medicine service. Ann Pharmacother. 2006;40(7-8):1261-6. PMID: 16804095; doi: 10.1345/aph.1G703.

26. Ameijeiras AH, González BC, Zúñiga VL. Prevalencia de prescripciónindicación de protectores gástricos en pacientes hospitalizados [A survey of gastroprotective drugs: prescription-indication in hospitalized patients]. Gac Sanit. 2007;21(5):412-5. PMID: 17916308. 
27. Sánchez-Cuén JA, Irineo-Cabrales AB, Bernal-Magaña G, Peraza-Garay F de J. Inadequate prescription of chronic consumption of proton pump inhibitors in a hospital in Mexico. Cross-sectional study. Rev Esp Enferm Dig. 2013;105(3):131-6. PMID: 23735019.

28. Chen WC, Li YD, Chiang PH, et al. Comparison of proton pump inhibitor and histamine-2 receptor antagonist in the prevention of recurrent peptic ulcers/erosions in long-term low-dose aspirin users: a retrospective cohort study. Biomed Res Int. 2014; 2014:693567. PMID: 25295267; doi: 10.1155/2014/693567.

29. States M, Draft EFG, Start E. Guideline on good pharmacovigilance practices (GVP). RegS09 [Internet]. 2012;(February):1-47. Available from: http://www.ema.europa.eu/docs/en_GB/document_library/ Regulatory_and_procedural_guideline/2017/08/WC500232767.pdf. Accessed in 2018 (Mar 26).

30. Carvalho APV, Silva V, Grande AJ. Avaliação do risco de viés de ensaios clínicos randomizados pela ferramenta da colaboração Cochrane. Diagn Tratamento. 2013;18(1):38-44

31. Wells GA, Shea B, O'Connell D, et al. The Newcastle-Ottawa Scale (NOS) for assessing the quality of nonrandomized studies in metaanalyses. Ottawa Hosp Res Inst. 2013;(3):1-4. Available from: http:// www.ohri.ca/programs/clinical_epidemiology/oxford.htm. Accessed in 2018 (Mar 22).

32. Schöller-Gyüre M, Kakuda TN, De Smedt G, et al. A pharmacokinetic study of etravirine (TMC125) co-administered with ranitidine and omeprazole in HIV-negative volunteers. Br J Clin Pharmacol. 2008;66(4):508-16. PMID: 18492125; doi: 10.1111/j.13652125.2008.03214.x.

33. Gottrand F, Kalach N, Spyckerelle C, et al. Omeprazole combined with amoxicillin and clarithromycin in the eradication of Helicobacter pylori in children with gastritis: A prospective randomized doubleblind trial. J Pediatr. 2001;139(5):664-8. PMID: 11713443; doi: 10.1067/ mpd.2001.118197.

34. Sezgin O, Barlas IO, Üçbilek E, Yengel E, Altintaş E. Modified sequential Helicobacter pylori eradication therapy using high dose omeprazole and amoxicillin in the initial phase in the extensive metaboliser Turkish patients for CYP2C19 polymorphism is ineffective. Acta Gastroenterol Belg. 2014;77(1):3-7. PMID: 24761684.

35. Veldhuyzen Van Zanten SJ, Chiba N, Armstrong D, et al. A randomized trial comparing omeprazole, ranitidine, cisapride, or placebo in Helicobacter pylori negative, primary care patients with dyspepsia: the CADET-HN Study. Am J Gastroenterol. 2005;100(7):1477-88. PMID: 15984968; doi: 10.1111/j.1572-0241.2005.40280.x.

36. Ummarino D, Miele $E$, Masi P, et al. Impact of antisecretory treatment on respiratory symptoms of gastroesophageal reflux disease in children. Dis Esophagus. 2012;25(8):671-7. PMID: 22236501; doi: 0.1111/j.14422050.2011.01301.x.

37. Soga T, Matsuura M, Kodama Y, et al. Is a proton pump inhibitor necessary for the treatment of lower-grade reflux esophagitis? J Gastroenterol. 1999;34(4):435-40. PMID: 10452673.
38. Manes G, Pieramico O, Perri F, et al. Twice-daily standard dose of omeprazole achieves the necessary level of acid inhibition for Helicobacter pylori eradication. A randomized controlled trial using standard and double doses of omeprazole in triple therapy. Dig Dis Sci. 2005;50(3):443-8. PMID: 15810623.

39. Schaffalitzky de Muckadell OB, Havelund T, Harling H, et al. Effect of omeprazole on the outcome of endoscopically treated bleeding peptic ulcers. Randomized double-blind placebo-controlled multicentre study. Scand J Gastroenterol. 1997;32(4):320-7. PMID: 9140153.

40. Mindiola AL, Fernandéz HM, Arciniegas DR, et al. Vitamin B 12 Deficiency Associated with Consumption of Proton Pump Inhibitors. Col Gastroenterol. 2017;32 (3):197-201. doi: 10.22516/25007440.150.

41. Varallo FR, Nadai TR, Oliveira ARA, et al. Potential Adverse Drug Events and Nephrotoxicity Related to Prophylaxis with Omeprazole for Digestive Disorders: A Prospective Cohort Study. Clin Therapeutics. 2018, 40(6)973-982. PMID: 29759903; doi: 10.1016/j.clinthera.2018.04.013.

42. Lazzerini PE, Bertolozzi I, Finizola F, et al. Proton Pump Inhibitors and serum magnesium levels in patient with torsades de pointes. Front Pharmacol. 2018;9:1-10. doi: 10.3389/fphar.2018.00363.

43. Zhou Y, Qiao L, Wu J, Hu H, Xu C. Comparison of the efficacy of octreotide, vasopressin, and omeprazole in the control of acute bleeding in patients with portal hypertensive gastropathy: A controlled study. J Gastroenterol Hepatol. 2002;17(9):973-9. PMID: 12167118.

44. Gomm W. von Holt K, Thomé, et al. Association of Proton Pump Inhibitors with Risk of Dementia. A Pharmacoepidemiological Claims Data Analysis. JAMA Neurol. 2016; 73(4):410-416. doi: 10.1001/ jamaneurol.2015.4791.

45. Imperatore $\mathrm{N}$, Tortora $\mathrm{R}$, Testa $\mathrm{A}$, et al. Proton pump inhibitors as risk factor for metabolic syndrome and hepatic steatosis in coeliac disease patient on gluten-free diet. J Gastroenterol. 2018;53(4):507:516. PMID: 28823009; doi: 10.1007/s00535-017-1381-7

46. Heijgen NA, de Ridder MA, Verhamme KM, et al. Are proton-pump inhibitors harmful for the semen quality of men in couples who are planning pregnancy? Fertil Steril. 2016;106(7):1666-1672. 27743698; doi: 10.1016/j.fertnstert.2016.09.010.

47. Yi X, Zhou Q, Wang C, et al. Concomitant Use of Proton Pump Inhibitors and Clopidogrel Is Not Associated with Adverse Outcomes after Ischemic Stroke in Chinese Population. J Stroke Cerebrovasc Dis. 2016; 25(12):2859-2867. doi: 10.1016/j.jstrokecerebrovasdis.2016.08.00.

48. Li DK, Yan P, Abou-Samra AB. Proton pump inhibitors are associated with accelerated development of cirrhosis, hepatic decompensation and hepatocellular carcinoma in noncirrhotic patients with chronic hepatitis $C$ infection: results from ERCHIVES. Aliment Pharmacol Ther. 2018; 47(2):246-258. PMID: 29105111 doi: 10.1111/apt.14391.

49. David-Neto E, Takaki KM, Agena F, et al. Diminished mycophenolic acid exposure caused by omeprazole may be clinically relevant in the first week posttransplantation. Ther Drug Monit. 2012;34(3):331-6. PMID: 22549498; doi: 10.1097/FTD.0b013e31824d6e8e. 
50. Bate CM, Booth SN, Crowe JP, et al. Omeprazole $10 \mathrm{mg}$ or $20 \mathrm{mg}$ once daily in the prevention of recurrence of reflux esophagitis. Solo Investigator Group. Gut. 1995;36(4):492-8. PMID: 7737552; doi: 10.1136/gut.36.4.492.

51. Marzio L, Biasco G, Cifani F, et al. Short- and long-term omeprazole for the treatment and prevention of duodenal ulcer, and effect on Helicobacter pylori. Am J Gastroenterol. 1995;90(12):2172-6. PMID: 8540510.

52. Valenzuela JE, Kogut DG, McCullough AJ, et al. Comparison of once-daily doses of omeprazole (40 and $20 \mathrm{mg}$ ) and placebo in the treatment of benign gastric ulcer: a multicenter, randomized, double-blind study. Am J Gastroenterol. 1996;91(12):2516-22. PMID: 8946978.

53. Labenz J, Beker JA, Dekker CP, et al. Doubling the omeprazole dose (40 mg b.d. vs. $20 \mathrm{mg}$ b.d.) in dual therapy with amoxycillin increases the cure rate of Helicobacter pylori infection in duodenal ulcer patients. Aliment Pharmacol Ther. 1997;11(3):515-22. PMID: 9218075.

54. Hasselgren $G$, Lind T, Lundell $L$, et al. Continuous intravenous infusion of omeprazole in elderly patients with peptic ulcer bleeding. Results of a placebo-controlled multicenter study. Scand J Gastroenterol. 1997;32(4):328-33. PMID: 9140154.

55. Annibale B, D'Ambra G, Luzzi l, et al. Does pretreatment with omeprazole decrease the chance of eradication of Helicobacter pylori in peptic ulcer patients? Am J Gastroenterol. 1997;92(5):790-4. PMID: 9149186.

56. Annibale B, Franceschi M, Fusillo M, et al. Omeprazole in patients with mild or moderate reflux esophagitis induces lower relapse rates than ranitidine during maintenance treatment. Hepatogastroenterology. 1998;45(21):742-51. PMID: 9684126.

57. Ladas SD, Tassios PS, Raptis SA. Selection of patients for successful maintenance treatment of esophagitis with low-dose omeprazole: use of 24-hour gastric pH monitoring. Am J Gastroenterol. 2000;95(2):374-80. PMID: 10685738; doi: 10.1111/j.1572-0241.2000.t01-1-01756.x.

58. Leite LP, Johnston BT, Just RJ, Castell DO. Persistent acid secretion during omeprazole therapy: a study of gastric acid profiles in patients demonstrating failure of omeprazole therapy. Am J Gastroenterol.. 1998;91(8):1527-31. PMID: 8759655.

59. Richter JE, Peura D, Benjamin SB, Joelsson B, Whipple J. Efficacy of omeprazole for the treatment of symptomatic acid reflux disease without esophagitis. Arch Intern Med. 2000;160(12):1810-6. PMID: 10871975

60. Klinkenberg-Knol EC, Nelis F, Dent J, et al. Long-term omeprazole treatment in resistant gastroesophageal reflux disease: efficacy, safety, and influence on gastric mucosa. Gastroenterology. 2000;1 18(4):661-9. PMID: 10734017.

61. Lind T, Mégraud F, Unge P, et al. The MACH2 study: role of omeprazole in eradication Helicobacter pylori with 1-week triple therapies. Gastroenterology. 1999;116(2):248-53. PMID: 9922303.

62. Blum AL, Arnold R, Stolte M, et al. Short course acid suppressive treatment for patients with functional dyspepsia: results depend on Helicobacter pylori status. The Frosch Study Group. Gut. 2000;47(4):473-80. PMID: 10986206.
63. Thjodleifsson B, Beker JA, Dekkers C, et al. Rabeprazole versus Omeprazole in preventing relapse of erosive or ulcerative gastroesophageal reflux disease: a double-blind, multicenter, European trial. The European Rabeprazole Study Group. Dig Dis Sci. 2000;45(5):845-53. PMID: 10795744.

64. Rabeneck L, Souchek J, Wristers K, et al. A double blind, randomized, placebo-controlled trial of proton pump inhibitor therapy in patients with uninvestigated dyspepsia. Am J Gastroenterol. 2002;97(12):3045-51 . PMID: 12492188; doi: 10.1111/j.1572-0241.2002.07123.x.

65. Esaki M, Aoyagi K, Matsumoto T, et al. Effects of omeprazole and famotidine on fibroblast growth factor-2 during artificial gastric ulcer healing in humans. Eur J Gastroenterol Hepatol. 2002;14(4):365-9. PMID: 11943947.

66. Armstrong D, Veldhuyzen van Zanten SJ, Barkun AN, et al. Heartburn-dominant, uninvestigated dyspepsia: a comparison of "PPI-start" and "H2-RA-start" management strategies in primary care The CADET-HR Study. Aliment Pharmacol Ther. 2005;21(10):1189-202. PMID: 15882239; doi: 10.1111/j.1365-2036.2005.02466.x.

67. Ohkusa T,MaekawaT,ArakawaT,etal.Effect of CYP2C19 polymorphism on the safety and efficacy of omeprazole in Japanese patients with recurrent reflux oesophagitis. Aliment Pharmacol Ther. 2005;21(11):1331-9. PMID: 15932363; doi: 10.1111/j.1365-2036.2005.02486.x.

68. Madisch A, Miehlke S, Neuber F, et al. Healing of lymphocytic gastritis after Helicobacter pylori eradication therapy - A randomized, doubleblind, placebo-controlled multicentre trial. Aliment Pharmacol Ther. 2006;23(4):473-9. PMID: 16441467; doi: 10.1111/j.13652036.2006.02778.x

69. Howden CW, Ballard ED, Koch FK, Gautille TC, Bagin RG. Control of 24-hour intragastric acidity with morning dosing of immediate-release and delayed-release proton pump inhibitors in patients with GERD. J Clin Gastroenterol. 2009;43(4):323-6. PMID: 18758373; doi: 10.1097/ MCG.0b013e31818a386e

70. Lundell L, Miettinen P, Myrvold HE, et al. Comparison of outcomes twelve years after antireflux surgery or omeprazole maintenance therapy for reflux esophagitis. Clin Gastroenterol Hepatol. 2009;7(12):1292-8; quiz 1260. PMID: 19490952; doi: 10.1016/j. cgh.2009.05.021

71. Ferreiro JL, Ueno M, Capodanno D, et al. Pharmacodynamic effects of concomitant versus staggered clopidogrel and omeprazole intake: results of a prospective randomized crossover study. Circ Cardiovasc Interv. 2010;3(5):436-41. PMID: 20858862; doi: 10.1161/ CIRCINTERVENTIONS.110.957829.

72. Hudzik B, Szkodzinski J, Danikiewicz A, et al. Effect of omeprazole on the concentration of interleukin- 6 and transforming growth factor- $\beta 1$ in patients receiving dual antiplatelet therapy after percutaneous coronary intervention. Eur Cytokine Netw. 2010;21(4):257-63. PMID: 21084246; doi: 10.1684/ecn.2010.0213.

73. Miwa H, Inoue K, Ashida K, et al. Randomised clinical trial: efficacy of the addition of a prokinetic, mosapride citrate, to omeprazole in the treatment of patients with non-erosive reflux disease - a double-blind, 
placebo-controlled study. Aliment Pharmacol Ther. 2011;33(3):323-32. PMID: 21118395; doi: 10.1111/j.1365-2036.2010.04517.x.

74. Klinkenberg-Knol EC, Festen HP, Jansen JB, et al. Long-term treatment with omeprazole for refractory reflux esophagitis: efficacy and safety. Ann Intern Med. 1994;121(3):161-7. PMID: 8017742.

75. Kreutz RP, Stanek EJ, Aubert R, et al. Impact of proton pump inhibitors on the effectiveness of clopidogrel after coronary stent placement: the clopidogrel Medco outcomes study. Pharmacotherapy. 2010;30(8):787-96. PMID: 20653354; doi:10.1592/phco.30.8.787.

76. van Boxel OS, van Oijen MG, Hagenaars MP, Smout AJ, Siersema PD. Cardiovascular and gastrointestinal outcomes in clopidogrel users on proton pump inhibitors: results of a large Dutch cohort study. Am J Gastroenterol. 2010;105(11):2430-6; quiz 2437. PMID: 20736935; doi: 10.1038/ajg.2010.334.

77. Teichert M, van Noord C, Uitterlinden AG, et al. Proton pump inhibitors and the risk of overanticoagulation during acenocoumarol maintenance treatment. Br J Haematol. 2011;153(3):379-85. PMID: 21418179; doi: 10.1111/j.1365-2141.2011.08633.x.

78. Kimura T, Morimoto T, Furukawa Y, et al. Association of the use of proton pump inhibitors with adverse cardiovascular and bleeding outcomes after percutaneous coronary intervention in the Japanese real world clinical practice. Cardiovasc Interv Ther. 2011;26(3):222-33. PMID: 24122589; doi: 10.1007/s12928-011-0063-2.

79. Korse CM, Muller M, Taal BG. Discontinuation of proton pump inhibitors during assessment of chromogranin A levels in patients with neuroendocrine tumours. Br J Cancer. 2011;105(8):1173-5. PMID: 21989216; doi: 10.1038/bjc.2011.380.

80. Ligumsky M, Lysy J, Siguencia G, Friedlander Y. Effect of long-term, continuous versus alternate-day omeprazole therapy on serum gastrin in patients treated for reflux esophagitis. J Clin Gastroenterol. 2001;33(1):32-5. PMID: 11418787.

81. Lin CF, Shen LJ, Wu FL, Bai CH, Gau CS. Cardiovascular outcomes associated with concomitant use of clopidogrel and proton pump inhibitors in patients with acute coronary syndrome in Taiwan. Br J Clin Pharmacol. 2012;74(5):824-34. PMID: 22364155; doi: 10.1111/j.13652125.2012.04250.x.

82. TsuzukiT, Okada H, Kawahara Y, et al. Proton pump inhibitor step-down therapy for GERD: a multi-center study in Japan. World J Gastroenterol. 2011;17(11):1480-7. PMID: 21472108; doi: 10.3748/wjg.v17.i11.1480.

83. Hassall E, Shepherd R, Koletzko S, et al. Long-term maintenance treatment with omeprazole in children with healed erosive oesophagitis: a prospective study. Aliment Pharmacol Ther. 2012;35(3):368-79. PMID: 22176465; doi: 10.1111/j.1365-2036.2011.04950.x.

84. Juurlink DN, Dormuth CR, Huang A, et al. Proton pump inhibitors and the risk of adverse cardiac events. Plos One. 2013;8(12):e84890. PMID: 24386430; doi: 10.1371/journal.pone.0084890.

85. Chularojanamontri L, Jiamton S, Manapajon A, et al. Cutaneous reactions to proton-pump inhibitors: a case-control study. J Drugs Dermatol. 2011;11(10):e43-7. PMID: 23134998.
86. Yamamoto I, Fukuda Y, Okui M, Tamura K, Shimoyama T. Proton pump inhibitor for Helicobacter pylori eradication in patients with peptic ulcer. J Clin Gastroenterol. 1995;20 Suppl 1:S38-42. PMID: 7673613.

87. Goh KL, Parasakthi N, Peh SC, Anderson PE, Tan KK. Prolonged treatment with omeprazole does not improve the eradication rate of Helicobacter pylori infection--a short report [corrected]. Singapore Med J. 1995;36(6):619-20. PMID: 8781634.

88. Noordzij JP, Khidr A, Evans BA, et al. Evaluation of omeprazole in the treatment of reflux laryngitis: a prospective, placebo-controlled, randomized, double-blind study. Laryngoscope. 2001;111(12):2147-51. PMID: 11802014; doi: 10.1097/00005537-200112000-00013.

89. Fujiwara Y, Higuchi K, Nebiki H, et al. Famotidine vs. omeprazole: a prospective randomized multicentre trial to determine efficacy in non-erosive gastro-oesophageal reflux disease. Aliment Pharmacol Ther. 2005;21 Suppl 2:10-8. PMID: 15943841; doi: 10.1111/j.13652036.2005.02468.x.

90. Liu BL, Li B, Zhang X, et al. A randomized controlled study comparing omeprazole and cimetidine for the prophylaxis of stress-related upper gastrointestinal bleeding in patients with intracerebral hemorrhage. J Neurosurg. 2013;118(1):115-20. PMID: 23061387; doi: 10.3171/2012.9.JNS12170.

91. Miner PB, McKean LA, Gibb RD, et al. Omeprazole-Mg 20.6 mg is superior to lansoprazole $15 \mathrm{mg}$ for control of gastric acid: A comparison of over-the-counter doses of proton pump inhibitors. Aliment Pharmacol Ther. 2010;31(8):846-51. PMID: 20146702; doi: 10.1111/j.1365-2036.2010.04258.x.

92. Sakurada T, Kawashima J, Ariyama S, et al. Comparison of adjuvant therapies by an $\mathrm{H}$ 2-receptor antagonist and a proton pump inhibitor after endoscopic treatment in hemostatic management of bleeding gastroduodenal ulcers. Dig Endosc. 2012;24(2):93-9. PMID: 22348833; doi: 10.1111/j.1443-1661.2011.01176.x.

93. Solana MJ, López-Herce J, Sánchez A, et al. 0.5 mg/kg versus 1 mg/kg of intravenous omeprazole for the prophylaxis of gastrointestinal bleeding in critically III children: a randomized study. J Pediatr. 2013;162(4):776782.e1. PMID: 23149178; doi: 10.1016/j.jpeds.2012.10.010.

94. Zairis MN, Tsiaousis GZ, Patsourakos NG, et al. The impact of treatment with omeprazole on the effectiveness of clopidogrel drug therapy during the first year after successful coronary stenting. Can J Cardiol. 2010;26(2):e54-7. PMID: 20151060.

95. Harjai KJ, Shenoy C, Orshaw P, et al. Clinical outcomes in patients with the concomitant use of clopidogrel and proton pump inhibitors after percutaneous coronary intervention: An analysis from the guthrie health off-label stent (GHOST) investigators. Circ Cardiovasc Interv. 2011;4(2):162-70. PMID: 21386091; doi: 0.1161/ CIRCINTERVENTIONS.110.958884.

96. Cappelletti Galante M, Garcia Santos V, Bezerra da Cunha GW. Assessment of the use of clopidogrel associated with gastroprotective medications in outpatients. Farm Hosp. 2012;36(4):216-9. PMID: 22115860; doi: 10.1016/j.farma.2011.06.011. 
97. Wang YF, Chen YT, Luo GC, et al. Proton-Pump Inhibitor Use and the Risk of First-Time Ischemic Stroke in the General Population: A Nationwide Population-Based Study. Am J Gastroenterol. 2017 Jul;112(7):1084-93. PMID: 28397874; doi: 10.1038/ajg.2017.101.

98. Erichsen R, Mikkelsen E, Pedersen L, Sørensen HT. Maternal use of proton pump inhibitors during early pregnancy and the prevalence of hypospadias in male offspring. Am J Ther. 2014;21(4):254-9. PMID: 22314213; doi: 10.1097/MJT.0b013e3182456a8f.

99. Restrepo $\mathrm{CH}$ et al. Impacto de los inhibidores de la bomba de protones en los niveles de vitamina B12 en pacientes con ERO estadio 5 en hemodiálisis. Experiencia de un centro en Manizales, Colombia. Acta Med Colomb [online]. 2017; 42(3):172-179.

100. Beijer HJ, Blaey CJ. Hospitalisations caused by adverse drug reactions (ADR): a meta-analysis of observational studies. Pharm World Sci. 2002;24(2):46-54. PMID: 12061133.

101. By the American Geriatrics Society 2015 Beers Criteria Update Expert Panel. American Geriatrics Society 2015 Updated Beers Criteria for Potentially Inappropriate Medication Use in Older Adults. J Am Geriatr Soc. 2015;63(11):2227-46. PMID: 26446832; doi:10.1111/jgs.13702.

102. Angiolillo DJ, Gibson CM, Cheng S, et al. Differential effects of omeprazole and pantoprazole on the pharmacodynamics and pharmacokinetics of clopidogrel in healthy subjects: randomized, placebo-controlled, crossover comparison studies. Clin Pharmacol Ther. 2011;89(1):65-74. PMID: 20844485; doi: 10.1038/clpt.2010.219.

Acknowledgements: FAPESP (Fundação de Amparo à Pesquisa do Estado de São Paulo) and PADC (Program for Support of Scientific Development of the School of Pharmaceutical Sciences of UNESP)

Sources of funding: FAPESP (Foundation for Research Support of the State of São Paulo) procedural number 2014/03468-6 (Scientific Initiation grant) and 2013/12681-2 (regular project); Conselho Nacional de Desenvolvimento Tecnológico (CNPq) [131206/2017-6]; Coordenação de Aperfeiçoamento de Pessoal de Nível Superior - Brasil (CAPES) - finance Code 001 and PADC (Program for Support of Scientific Development of the School of Pharmaceutical Sciences of UNESP)

Conflict of interest: None

Date of first submission: January 31, 2018

Last received: March 20, 2018

Accepted: March 22, 2018

\section{Address for correspondence:}

Patrícia de Carvalho Mastroianni

São Paulo State University (UNESP), School of Pharmaceutical Sciences

Rodovia Araraquara-Jaú, Km 1, s/no

Campus Ville — Araraquara (SP) — Brazil

CEP 14800-903

Tel. (+55 16) 3301-6977

E-mail: patriciamastroianni@yahoo.com.br 